\title{
Phagocytosis-Associated Functions in Neonatal Monocyte-Derived Macrophages
}

\author{
CHRISTIAN P. SPEER, MANFRED GAHR, MARION WIELAND, AND STEFAN EBER \\ Department of Pediatrics, University of Göttingen, Federal Republic of Germany
}

\begin{abstract}
Using a Teflon culture system we analyzed different aspects of cell maturation and phagocytic activities in neonatal monocyte-derived macrophages. Morphological and cytochemical characteristics as well as the protein composition of neonatal macrophages were identical with those of adult controls; actin binding protein $(265,000 \mathrm{Da})$, myosin $(210,000), \alpha$-actinin $(102,000)$ and actin $(42,000)$ could be identified in cells from either source. All phagocytic functions were shown to be perfectly normal in neonatal macrophages when compared with adult cells: random migration, chemotactic response to zymosanactivated serum and formyl-methionyl-leucyl-phenylalanin, ingestion, and killing of Staphylococcus aureus, phagocytosis-associated chemiluminescence, production of oxygen intermediates (superoxide anion, $\mathrm{O}_{2}^{-}$; hydrogenperoxide, $\mathrm{H}_{2} \mathrm{O}_{2}$ ). Phorbol myristate acetate-stimulated $\mathrm{O}_{2}^{-}$-generation by $1 \times 10^{5}$ macrophages was $11.8 \pm 4.7$ $\mathrm{nmol} / \mathrm{h}$ for neonates, and 10.2 \pm 3.9 for controls; production of $\mathrm{H}_{2} \mathrm{O}_{2}$ was $7.6 \pm 3.5 \mathrm{nmol} / \mathrm{h}$ in neonatal macrophages and $6.4 \pm 2.8$ in adult controls. It is unlikely, then, that the increased susceptibility of human neonates to systemic bacterial infections can be related to an abnormality in the essential phagocyte functions of macrophages. (Pediatr Res 24: 213-216, 1988)
\end{abstract}

\section{Abbreviations}

FMLP, formyl-methionyl-leucyl-phenylalanin

PMA, phorbol myristate acetate

$\mathrm{O}_{2}^{-}$superoxide anion

$\mathrm{H}_{2} \mathrm{O}_{2}$, hydrogen peroxide

HBSS, Hanks' balanced salt solution

SDS, sodium dodecyl sulfate

.OH, hydroxyl radical

PBS, phosphate-buffered saline

In newborns, who suffer an increased susceptibility to serious systemic infections, subnormal phagocyte functions have been described. Neutrophils from neonates showed a decreased deformability (1) and a marked deficiency in movement toward different chemotactic stimuli (2-6). In addition generation of . $\mathrm{OH}$ by neonatal neutrophils was shown to be decreased (7). However, neonatal monocytes exhibited basically normal phagocytic functions when compared with adult cells (8). The functions of neonatal macrophages have not been fully explored. Macrophages from newborns synthesize humoral host defense factors such as complement components $\mathrm{C} 2, \mathrm{C} 4$ to a similar extent as phagocytes from adults $(9,10)$; fibronectin production

Received October 12, 1987; accepted April 7, 1988

Correspondence Christian P. Speer, M.D., Universitäts-Kinderklinik, RobertKoch-Str. 40, D-3400 Göttingen, Federal Republic of Germany.

Supported by Grant Sp 239/2-2 from the Deutsche Forschungsgemeinschaft. was shown to be decreased in neonatal macrophages (9). Macrophages from newborns who had been activated by interferon$\gamma$ effectively killed or inhibited replication of toxoplasma gondii (11), presentation of bacterial $\mathrm{Ag}$, and production of interleukin 1 was normal in cord blood monocytes/macrophages $(12,13)$. However, it has been suggested, that the decreased production of interferon- $\gamma$ by human neonatal cells (13) could be due to a functionally immature macrophage (14).

Our study was initiated to examine the principal phagocyte activities of monocyte-derived macrophages in response to inflammation, i.e. chemotaxis, phagocytosis, killing, and generation of oxygen metabolites. Morphological studies included a detailed analysis of the protein composition of macrophages.

\section{MATERIALS AND METHODS}

Cell separation. Umbilical venous blood was withdrawn from the placenta into heparin $(1-20 \mathrm{U} / \mathrm{ml})$ immediately after delivery of healthy term newborns who were products of an uncomplicated pregnancy, normal labor, and vaginal delivery $(n=78)$; general anesthesia was not used in any of the deliveries. Mothers were not receiving a special diet or medications, including antibiotics, within 4 wk before delivery. Blood from healthy adult donors similarly anticoagulated was drawn simultaneously with the procurement of cord blood. Mononuclear cells were isolated by dextran sedimentation and separation by Ficoll-Hypaque density gradient as previously described (15).

Mononuclear cells were resuspended in RPMI 1640 (with PenStrep, L-glutamine and HBSS, Flow Laboratories, Meckenheim, FRG) at a final concentration of $1 \times 10^{6}$ cells $/ \mathrm{ml}$. A total of 5 $\mathrm{ml}$ samples was placed into $100-\mathrm{mm}$ diameter culture dishes (Falcon, Oxnard, MA). After a $2 \mathrm{~h}$ incubation at $37^{\circ} \mathrm{C}$ in $5 \%$ $\mathrm{CO}_{2} / 95 \%$ air, nonadherent cells were removed by gently aspirating the supernatant fluid and repeated washings with media (three times). Monocyte suspensions were then prepared by recovering adherent cells after incubation in PBS, $\mathrm{pH} 7.4$, containing $2 \mathrm{mmol}$ EDTA at $4^{\circ} \mathrm{C}$ for $15 \mathrm{~min}$ and gently resuspending with a rubber policeman. These suspensions contained about $90 \%$ monocytes, identified by nonspecific esterase stain.

Cells were pooled, centrifuged, and resuspended at a concentration of $1 \times 10^{5} / \mathrm{ml}$ in RPMI 1640 without serum. In a volume of $50 \mathrm{ml}$ the cell suspension was added to Teflon culture bags and the cells were cultured for 10 days at $37^{\circ} \mathrm{C}$ in $5 \% \mathrm{CO}_{2} / 95 \%$ air. After 10 days in culture the macrophages were washed and again examined for nonspecific esterase activity and in some experiments for peroxidase activity (16). More than $95 \%$ of the macrophages were viable by a trypan blue exclusion test. In airdried cell smears macrophages were identified by monoclonal mouse anti-human macrophage antibodies (M 780) detected by use of alkaline phosphatase labeled antibodies (Dakopatts, Giostrup, Denmark).

SDS-polyacrylamide gel electrophoresis of macrophages. Approximately $5 \times 10^{6}$ macrophages were lysed in $0.025 \mathrm{M}$ Tris(hydroxymethyl) aminomethane- $\mathrm{HCl}$ buffer, $\mathrm{pH} 8.2$, containing 
$0.19 \mathrm{M}$ glycerine, $5 \% \mathrm{w} / \mathrm{v}$ SDS, and $5 \% \mathrm{w} / \mathrm{v}$ mercaptoethanole. The samples were incubated at $60^{\circ} \mathrm{C}$ for $15 \mathrm{~min}$, diluted with aqua dest. (1:5), and kept at $100^{\circ} \mathrm{C}$ for $7 \mathrm{~min}$. After centrifugation $(10 \mathrm{~min}$ at $48,000 \times g)$ the supernatants were diluted 1:2 with sample buffer according to Laemmli (17). SDS-polyacrylamide gel electrophoresis was performed using the discontinuous buffer system (17) with a gradient of acrylamide concentration ranging from 5-17\%. Proteins were stained with Coomassie blue G 250 . Molecular weight markers (Bio-Rad Laboratories, Richmond, $\mathrm{CA})$ were applied to the same gel. The standard proteins were myosin (apparent mol. wt. 200,000), $\beta$-galactosidase $(116,250)$, phosphorylase B $(92,500)$, bovine serum albumin $(66,200)$, ovalbumin $(45,000)$, carbonic anhydrase $(31,000)$, soybean trypsin inhibitor $(21,500)$, and lysozyme $(14,400)$. In addition erythrocyte membrane proteins extracted according to Dodge et al. (18) were used as reference samples. The mol. wt. of the prominent macrophage proteins were determined by applying a calibration curve from known standards according to Weber and Osborn (19).

Chemotaxis. Chemotaxis of macrophages was evaluated using a modification of the Boyden chamber technique (Celloplex, Basel, Switzerland) as recently described (20). Pooled serum activated by zymosan $(50 \mathrm{mg} / \mathrm{ml}$ Sigma, Munich, FRG) and FMLP $10^{-5} \mathrm{M}$ (Sigma) were used as chemoattractants.

Phagocytosis and bactericidal assay. A modification of the method of Quie et al. was used (21). Phagocytosis by macrophages was measured as the decrease in the number of viable extracellular bacteria during incubation of bacteria and macrophages in the presence of serum. The $1 \mathrm{ml}$ reaction mixture consisted of $0.3 \mathrm{ml} \mathrm{HBSS}, 0.1 \mathrm{ml}$ pooled human serum, approximately $5 \times 10^{6}$ bacteria (Staphylococcus aureus $502 \mathrm{~A}$ ) in 0.3 $\mathrm{ml} \mathrm{HBSS}$ and $2.5 \times 10^{6}$ macrophages in $0.3 \mathrm{ml}$ HBSS. The tubes were chilled in an ice bath, and then serum, bacteria, and phagocytes were added in that order. Samples were incubated at $37^{\circ} \mathrm{C}$ and aliquots $(50 \mu \mathrm{l})$ were removed at $0,30,60$, and 90 min. The aliquots were added to ice cold HBSS $(450 \mu \mathrm{l})$ and the cells immediately centrifuged at $200 \times g$ for $2 \mathrm{~min}$ at $40^{\circ} \mathrm{C}$ and the supernatant was diluted to make agar pour plates for colony counting. Intracellular killing of $S$. aureus was measured as recently described (20).

Chemiluminescence. Luminol-dependent chemiluminescence was measured using a luminometer (LKB-Wallac 1250); details have been recently published (20).

Measurement of $\mathrm{O}_{2}^{-}$and $\mathrm{H}_{2} \mathrm{O}_{2}$. Release of $\mathrm{O}_{2}^{-}$by $1 \times 10^{5}$ macrophages $/ \mathrm{ml}$ in suspension was determined by superoxide dismutase inhibitable reduction of cytochrome $\mathrm{C}$ using PMA (Consolidated Midland Corporation, Brewster, NY) or opsonized zymosan as stimulus (22). The formation of $\mathrm{H}_{2} \mathrm{O}_{2}$ by macrophages $\left(1 \times 10^{5} / \mathrm{ml}\right.$ reaction mixture) was assayed by measuring the amount of fluorescence due to the oxidation of homovanillic acid by $\mathrm{H}_{2} \mathrm{O}_{2}$ catalyzed by horseradish peroxidase as recently described (20). Assays were performed in duplicate.

\section{RESULTS}

Morphology and cytochemical characteristics of cord blood macrophages. After 10 days in culture monocyte-derived macrophages from neonates and adults demonstrated similar heterogeneous morphological changes: increase in cell size, ovaloid shape, and development of a few dendritic processes. A total of $96.6 \pm 4.1 \%$ of the cord blood macrophages stained for esterase and the corresponding percentage of control macrophages was $98.2 \pm 3.4$ (mean $\pm 1 \mathrm{SD}, n=12$ ). Peroxidase staining was negative in cells from either source. A total of $93.3 \pm 2.5 \%$ of the neonatal macrophages was detected by monoclonal mouse anti-human macrophage antibodies (Dako-macrophages, EBM 11, Dako Corp., Santa Barbara, CA) and $98.8 \pm 0.8$ of controls.

SDS-polyacrylamide gel electrophoresis. In macrophages from neonates and adults several prominent protein bands could be

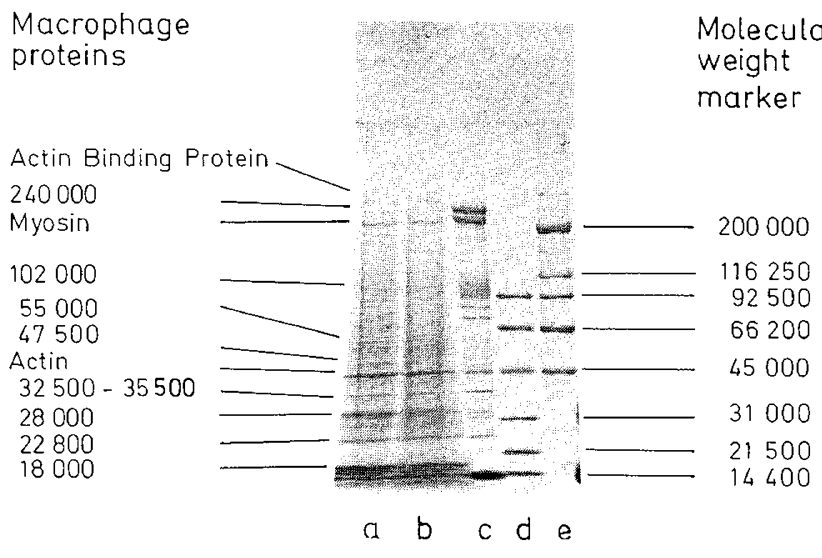

Fig. 1. SDS-polyacrylamide gel electrophoresis of macrophage proteins, erythrocyte membrane proteins and molecular weight markers. Right, apparent m.w. of the marker proteins. Left, m.w. of prominent macrophage proteins. $a$, macrophage extract from adult donor; $b$, macrophage extract from a newborn infant; $c$, erythrocyte membrane proteins which were used as standards: spectrin $(220,000-240,000)$, band 3 $(90,000-120,000)$, actin $(42,000)$, glyceraldehyde-3-phosphate dehydrogenase $(35,000)$, band $7(27,000-29,000)$, and $\mathrm{Hb}(17,000)(28)$; $d$, low m.w. markers; $e$, high m.w. markers.

found (Fig. 1). On the top of the gel there is a triplet of proteins containing actin-binding protein $(265,000)$, an unidentified second band $(240,000)$, and myosin $(210,000)$. A distinct band at $102,000 \mathrm{Da}$ probably represents $\alpha$-actinin. The next protein $(55,000)$ is most likely vimentin. Actin $(42,000)$ can be identified by comparison with erythrocyte actin. A triplet of bands with a mol. wt. ranging from 32,500 to 35,500 is found below actin. The first of the three bands comigrates with erythrocyte glyceraldehyde-3-phosphate dehydrogenase. The protein with a mol. wt. of $28,000 \mathrm{Da}$ is similar to tropomyosin. Some bands with an apparent mol. wt. of about 18,000 Da should contain profilin and myosin light chain. Two prominent bands with a mol. wt. of 47,500 and 22,800 could not be identified. All proteins are present to an identical amount in macrophages from newborns and adult controls.

Random migration and chemotaxis. As demonstrated in Table 1 during a 90 -min assay random migration of cord blood macrophages was similar to that of adult controls. In addition the chemotactic response to zymosan-activated serum was identical in macrophages from neonates and adults. A mildly decreased chemotaxis of cord blood macrophages was observed in response to the chemotactic peptide FMLP.

Phagocytosis and bactericidal capacity of macrophages. As shown in Figure 2 neonatal macrophages exhibited normal phagocytosis of opsonized $S$. aureus. Similarly neonatal macrophages killed $S$. aureus as efficiently as macrophages from adults.

Chemiluminescence. After stimulation with PMA macrophages from neonates and adult controls generated small amounts of chemiluminescence (Fig. 3); both peak values and kinetics of the reaction were identical in cells of either source. Chemiluminescence induced by opsonized zymosan gradually increased to reach a peak at about $15 \mathrm{~min}$; the peak value was about two-third of that achieved with PMA.

Production of $\mathrm{O}_{2}^{-}$and $\mathrm{H}_{2} \mathrm{O}_{2}$. Generation of oxygen metabolites by neonatal macrophages and the extent of $\mathrm{O}_{2}^{-}$and $\mathrm{H}_{2} \mathrm{O}_{2}$ released by macrophages from neonates and adult controls are summarized in Table 2 .

Production of superoxide anion in unstimulated macrophages was slightly elevated in cells from neonates. However, after stimulation with PMA and during phagocytosis of opsonized zymosan macrophages from neonates and adults similarly generated $\mathrm{O}_{2}^{-}$and $\mathrm{H}_{2} \mathrm{O}_{2}$. 


\section{DISCUSSION}

Macrophages that are present in various anatomical sites, play a central role in cellular host defense; their main functions include response to inflammation, immunoregulatory activities, microbicidal as well as tumoricidal capacities (23). Macrophages are motile cells that are capable of migrating directionally along chemotactic gradients (24). Branching network of actin filaments are the principal structures observed in the moving regions of cytoplasma (25).

The antimicrobial and anticellular activities of macrophages depend to a large extent on their ability to ingest various particles and to reduce oxygen molecules to reactive intermediates $\left(\mathrm{O}_{2}^{-}\right.$, $\left.\mathrm{H}_{2} \mathrm{O}_{2}, \cdot \mathrm{OH}\right)$. These phagocytic functions of macrophages have not been evaluated in the human neonate. Using a Teflon culture system we analyzed different aspects of cellular activities in nonadherent monocyte-derived macrophages.

Morphological and cytochemical characteristics of neonatal macrophages were identical with those of adult controls (9). In a detailed analysis of the protein composition of macrophages no quantitative and qualitative differences were found between cells from either source.

Actin binding protein, $\alpha$-actinin, myosin, and actin could be identified in both macrophages. Random migration and a chemotactic response to zymosan-activated serum was identical in cells from newborns and adults. Additionally ingestion of opson-

Table 1. Random migration and chemotaxis of macrophages from neonates and adult controls in response to zymosanactivated serum or FMLP $\left(10^{-5} \mathrm{M}\right)$

\begin{tabular}{lcc}
\hline \multirow{2}{*}{ Chemoattractant } & \multicolumn{2}{c}{$\begin{array}{c}\text { Macrophage migration } \\
(\mu \mathrm{m})^{*}\end{array}$} \\
\cline { 2 - 3 } \multicolumn{1}{c}{ Neonate } & Adult \\
\hline None & $47.7 \pm 7.3 \dagger$ & $53.2 \pm 6.4$ \\
Zymosan-activated serum & $128 \pm 25.3$ & $141 \pm 29.6$ \\
FMLP & $73.9 \pm 16$ & $89.8 \pm 12.3$ \\
\hline
\end{tabular}

* The migratory distance was expressed in $\mu \mathrm{m}$.

$\dagger$ Mean \pm SD of averages of duplicate samples; 12 paired experiments were performed with macrophages from either source. ized $S$. aureus was normal in neonatal macrophages as well as in monocytes from newborns (8).

During phagocytosis of opsonized zymosan and perturbation with PMA macrophages from neonates and adults generated considerable amounts of $\mathrm{O}_{2}^{-}$and $\mathrm{H}_{2} \mathrm{O}_{2}$; no differences in the production of either oxygen metabolites were found. Hydroxyl radical production in neonatal monocytes was also shown to be normal (27).

Generation of oxygen radicals in monocytes and monocytederived macrophages activated by lipopolysaccharide was identical in cells from newborns and adults $(10,27)$. However, generation of chemiluminescence was similarly depressed in macrophages of either source, when compared with monocytes (20); this disparity between a normal generation of oxygen metabolites and a decreased chemiluminescence might be explained at least in part by a reduction in the content of excitable substrates

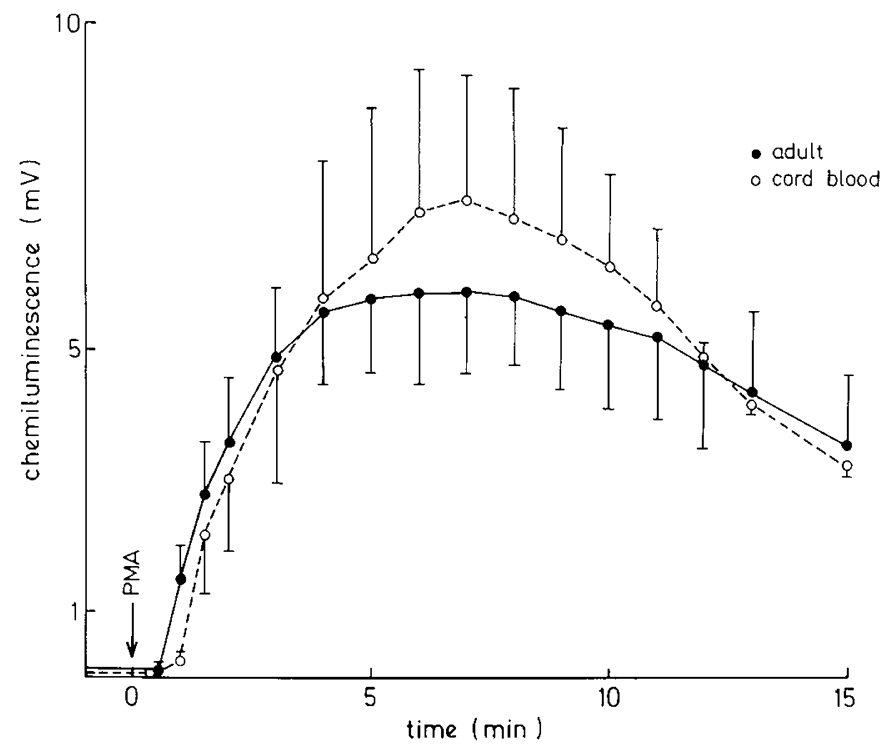

Fig. 3. Generation of chemiluminescence by $1 \times 10^{5}$ macrophages from neonate and adult controls after stimulation with PMA. Mean values $( \pm \mathrm{SD})$ are plotted for six experiments with either cell.

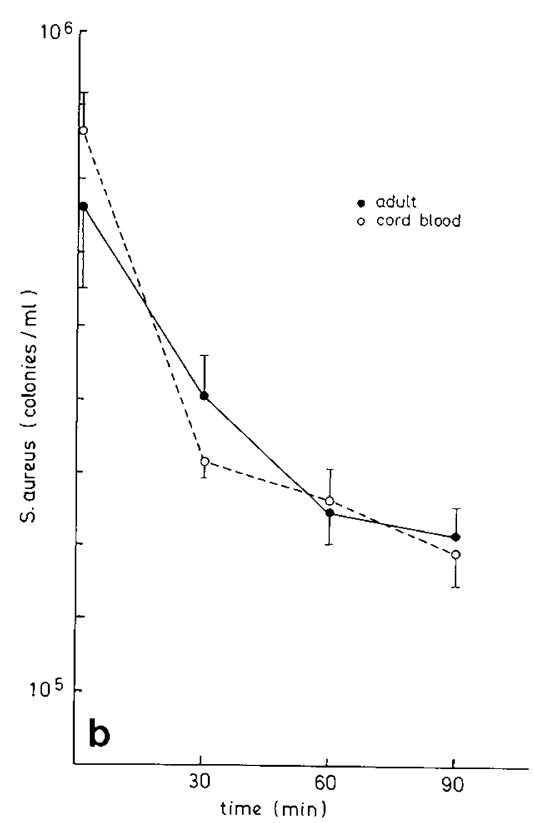

Fig. 2. Phagocytosis of $S$. aureus by macrophages from neonates and adults $(a)$. Bactericidal activity of macrophages from neonates and adults. Values represent mean \pm SD for six experiments performed in duplicate $(b)$. 
Table 2. Generation of $\mathrm{O}_{2}^{-}$and $\mathrm{H}_{2} \mathrm{O}_{2}$ in macrophages from neonates and adults

\begin{tabular}{llcc}
\hline Stimulus & Macrophages & $\begin{array}{c}\mathrm{O}_{2}^{-*} \\
\left(\mathrm{nmol} / 10^{5}\right. \\
\text { cells/h) }\end{array}$ & $\begin{array}{c}\mathrm{H}_{2} \mathrm{O}_{2} \dagger \\
\left(\mathrm{nmol} / 10^{5}\right. \\
\text { cells/h) }\end{array}$ \\
\hline None & Neonate & $4.1 \pm 1.9 \ddagger$ & $1.2 \pm 0.6$ \\
& Adult & $2.5 \pm 0.9$ & $0.7 \pm 0.5$ \\
PMA & Neonate & $11.8 \pm 4.7$ & $7.6 \pm 3.5$ \\
& Adult & $10.2 \pm 3.9$ & $6.4 \pm 2.8$ \\
Zymosan & Neonate & $9.1 \pm 2.3$ & $6.1 \pm 3.2$ \\
& Adult & $8.4 \pm 2.7$ & $5.9 \pm 3.7$ \\
\hline
\end{tabular}

$* \mathrm{O}_{2}^{-}$was quantitated by its capacity to reduce ferricytochrome c.

$\uparrow \mathrm{H}_{2} \mathrm{O}_{2}$ was measured by following the increase of fluorescence due to the oxidation of homovanillic acid catalyzed by horseradish peroxidase.

$\$$ Mean $\pm \mathrm{SD}$ of averages of duplicate samples $(n=12)$.

during long term culture of macrophages. The bactericidal capacity of neonatal macrophages against $S$. aureus was as effective as that from control cells. Studies of microbicidal activity by neonatal monocytes similarly indicate that phagocytic killing of various microorganisms is approximately normal (8). However, a depression of microbicidal capacity could be demonstrated when neonatal monocytes were challenged by group B Streptococcus (26); the mechanisms of this impairment is unknown.

The results of our study demonstrate that monocytes from newborns and adults similarly mature into macrophages during long-term culture. In addition neonatal macrophages exhibit perfectly normal phagocytic activities when compared with adult cells. It is unlikely, then, that the increased susceptibility of neonates to systemic bacterial infections can be related to an abnormality in the essential phagocyte functions of macrophages.

\section{REFERENCES}

1. Miller ME 1979 Phagocyte function in the neonate: Selected aspects. Pediatrics 64 (suppl):709-712

2. Miller ME 1971 Chemotactic function in the human neonate: humoral and cellular aspects. Pediatr Res 5:487-492

3. Pahwa SG, Pahwa R, Grimes E, Smithwick E 1977 Cellular and humora components of monocyte and neutrophil chemotaxis in cord blood. Pediatr Res 11:677-680

4. Klein RB, Fischer TJ, Gard SE, Biberstein M, Rich KC, Stiehm ER 1977 Decreased mononuclear and polymorphonuclear chemotaxis in human newborns, infants and young children. Pediatrics 60:467-472

5. Tono-Oka T, Nakayama M, Uehara H, Matsumoto S 1979 Characteristics of impaired chemotactic function in cord blood leukocytes. Pediatr Res 13:148151

6. Yegin O 1983 Chemotaxis in childhood. Pediatr Res 17:183-187

7. Ambruso DR, Altenburger KM, Johnston RB Jr 1979 Defective oxidative metabolism in newborn neutrophils: discrepancy between superoxide anion and hydroxyl radical generation. Pediatrics 64:722-725

8. Speer CP, Johnston RB Jr 1984 Phagocyte function. In: Ogra PL (ed) Neonatal Infections. Nutritional and Immunologic Interactions. Grune \& Stratton, New York, pp 21-26

9. Gerdes JS, Douglas SD, Kolski GB, Yoder MC, Polin RA 1984 Decreased fibronectin biosynthesis by human cord blood mononuclear phagocytes in vitro. J Leukocyte Biol 35:91-99

10. Strunk RC, Murrow BW, Thilo E, Kuke KS, Johnson EG 1985 Normal macrophage function in infants receiving intralipid by low-dose intermittent administration. J Pediatr 106:640-645

11. Wilson CB, Westall J 1985 Activation of neonatal and adult human macrophages by alpha-, beta-, and gamma-interferons. Infect Immun 49:351-356

12. Zlabinger GJ, Mannhalter JW, Eibl MM 1983 Cord blood macrophages present bacterial antigen (Escherichia coli) to paternal T-cells. Clin Immunol Immunopathol 28:405-412

13. Wilson CB, Estall J, Johnston L, Lewis DB, Dower SK, Alpert AR 1986 Decreased production of interferon-gamma by human neonatal cellsintrinsic and regulatory deficiencies. J Clin Invest 77:860-867

14. Taylor S, Bryson YJ 1985 Impaired production of $\gamma$-interferon by newborn cells in vitro is due to a functionally immature macrophage. $\mathbf{J}$ Immunol 134:1493-1497

15. Speer CR, Pabst MJ, Hedegaard HB, Rest RF, Johnston RB Jr 1984 Enhanced release of oxygen metabolites by monocyte-derived macrophages exposed to proteolytic enzymes: activity of neutrophil elastase and cathepsin G. J Immunol 133:2151-2156

16. Tucker SB, Pierre RV, Jordan RE 1977 Rapid identification of monocytes in a mixed mononuclear cell preparation. J Immunol Methods 14:267-269

17. Laemmli UK 1970 Cleavage of structural proteins during the assembly of head of bacteriophage T4. Nature 227:680-685

18. Dodge JT, Mitchel C, Hanahan DJ 1963 The preparation and chemical characteristics of hemoglobin free ghosts of human erythrocytes. Arch Biochem Biophys 100:119-130

19. Weber K, Osborn M 1969 The reliability of molecular weight determination by dodecyl-sulfate-polyacrylamide gel electrophoresis. J Biol Chem 244:4406-4412

20. Speer CP, Wieland M, Gahr M 1986 Phagocytic activities in neonatal monocytes. Eur J Pediatr 145:418-42

21. Quie PG, White JG, Holmes B, Good RA 1967 In vitro bactericidal capacity of human polymorphonuclear leukocytes; diminished activity in chronic granulomatous disease of childhood. J Clin Invest 46:668-672

22. Johnston RB Jr, Keele BB Jr, Misra HB, Lehmeyer JE, Webb LS, Baehner RL, Rajagopalan KV 1975 The role of superoxide anion generation in phagocytic bactericidal activity. Studies with normal and chronic granulomatous disease leukocytes. J Clin Invest 55:1357-1372

23. Douglas SD, Musson RA 1986 Phagocytic defects-monocytes/macrophages. Clin Immunol Immunopathol 40:62-68

24. Snyderman R 1985 Stimulus-response coupling of a chemoattractant receptor on mononuclear phagocytes. In: Furth R van (ed) Mononuclear Phagocytes, Characteristics, Physiology and Function. Martinus Nijhoff Publishers, Dordrecht/The Netherlands, pp 343-349

25. Hartwig $\mathrm{JH}$, Stossel TP 1985 Macrophage movements. In: Furth $\mathrm{R}$ van (ed) Mononuclear Phagocytes, Characteristics, Physiology and Functions. Martinus Nijhoff Publishers, Dordrecht/The Netherlands, pp 329-336

26. Marodi L, Leijh PCJ, Furth R van 1984 Characteristics and functional capacities of human cord blood granulocytes and monocytes. Pediatr Res 18:11271131

27. Speer CP, Ambruso DR, Grimsley J, Johnston RB Jr 1985 Oxidative metabolism in cord blood monocytes and monocyte-derived macrophages. Infect Immun 50:919-921

28. Cohen CM 1983 The molecular organization of red cell membrane skeleton. Semin Hematol 20:141-158 